\title{
Stability and Repair of DNA in Hyperthermophilic Archaea
}

\author{
Dennis W. Grogan* \\ Department of Biological Sciences, University of Cincinnati, \\ Cincinnati, Ohio 45221-0006 USA
}

\begin{abstract}
Evolutionary and physiological considerations argue that study of hyperthermophilic archaea should reveal new molecular aspects of DNA stabilization and repair. So far, these unusual prokaryotes have yielded a number of genes and enzymatic activities consistent with known mechanisms of excision repair, photo-reversal, and trans-lesion synthesis. However, other DNA enzymes of hyperthermophilic archaea show novel biochemical properties which may be related to DNA stability or repair at extremely high temperature but which remain difficult to evaluate rigorously in vivo. Perhaps the most striking feature of the hyperthermophilic archaea is that all of them whose genomes have been sequenced lack key genes of both the nucleotide excision repair and DNA mismatch repair pathways, which are otherwise highly conserved in biology. Although the growth properties of these micro-organisms hinder experimentation, there is evidence that some systems of excision repair and mutation avoidance operate in Sulfolobus spp. It will therefore be of strategic significance in the next few years to formulate and test hypotheses in Sulfolobus spp. and other hyperthermophilic archaea regarding mechanisms and gene products involved in the repair of UV photoproducts and DNA mismatches.
\end{abstract}

\section{Introduction}

The proposition that DNA succeeded RNA as a genetic material in the pre-biotic world because of its greater stability is perhaps familiar to biologists. What may be less familiar is the idea that DNA's stability is wholly inadequate for the biological success of any modern cellular organism. In reality, a wide gap separates the intrinsic chemical stability of DNA on one hand and the stringent demands of accurate genome propagation on the other. In cellular organisms, this stability gap is bridged by diverse enzymes which must groom DNA continuously in order for it to be replicated accurately at the proper time in the life-cycle of the cell (Lindahl and Wood 1999). These enzymes define at least seven major repair pathways, including two that reverse damage (alkyl transfer, photo-reversal), three that remove lesions prior to re-synthesis (base excision repair, nucleotide excision repair, mismatch repair), and

*For correspondence. Email grogandw@email.uc.edu. two that allow replication to by-pass damage (homologous recombination, trans-lesion synthesis). The number and diversity of repair enzymes reflect the variety of lesions that can arise in DNA, and the threat that each lesion poses to an organism's immediate reproduction and the long-term survival of its lineage.

The major DNA repair pathways were identified through the sophisticated genetic analysis made possible by microorganisms such as Escherichia coli and Saccharomyces cerevisiae. The historical success of this approach reflects the conservation of these pathways from bacteria to humans, and the fact that, in micro-organisms, they are not essential for viability and can be inactivated by single mutations. One cannot guarantee, however, that all aspects of DNA stability and repair in biology fulfill these criteria. Some components of the nucleotide excision repair (NER) machinery of eukaryotes, for example, double as components of the basal transcription machinery (Prakash and Prakash 2000), making it difficult to isolate the corresponding mutants. In addition, the extreme molecular divergence represented among simple micro-organisms implies that no single species, genus, or even phylum can adequately represent all microbial life at the cellular or molecular levels (Woese et al. 1990). The bacterium Deinococcus radiodurans provides a dramatic example of how this diversity can manifest itself in terms of DNA repair. $D$. radiodurans survives extremely high doses of ionizing radiation (5000 Gy, e.g.) with negligible mutation; this radiation resistance reflects a highly efficient system of double-strand break repair, whose biological relevance seems to be survival of dessication stress rather than radiation [reviewed by Battista (1997)]. Experimental study of this bacterium and sequencing of its genome have revealed several unusual molecular features, yet the importance and roles of these various features in the radio-resistance of this bacterium continue to be debated (Battista 2000; Karlin and Mrazek 2001).

It seems logical, therefore, that additional diversity of DNA stabilization and repair remains to be found in microorganisms unrelated to the traditional model species and adapted to survive harsh environmental conditions. All archaea, by definition, fit the first criterion (Woese et al. 1990). Furthermore, many known archaeal species grow optimally under conditions of temperature, $\mathrm{pH}$, or salt concentration that kill "model" species (including $D$. radiodurans), and thus fit the second criterion, as well. Of the environmental extremes accommodated by archaea, high temperature has particular significance for genomic integrity, as it directly destabilizes the primary and secondary structure of DNA and cannot be excluded from the interior of microbial cells. A number of archaea cultured from geothermal environments grow optimally at $80^{\circ} \mathrm{C}$ or above; these species, here designated "hyperthermophilic archaea" (Stetter 1996), therefore provide a particularly 
significant context in which to investigate the molecular diversity of DNA stability and repair. This review attempts a selective, critical overview of recent progress on this topic and questions of current significance. It emphasizes molecular mechanisms of DNA repair, and does not address genome stability as determined by genetic processes such as rearrangements, mutation, and gene loss or acquisition. Prior reviews on the present topic include Grogan (1998; 2000) and White (2003).

\section{"Ordinary" enzymes, and those with unusual features}

Many of the genetic problems posed by life at high temperature reflect the acceleration of spontaneous DNA decomposition reactions (such as depurination and deamination) that also occur in mesophiles. In one sense, therefore, hyperthermophiles face "ordinary problems writ large", and would seem able to solve them by expressing thermostable versions of known DNA repair enzymes at suitable levels. This idea, articulated by Lindahl (1993), provides an appropriate null hypothesis from which to first approach specific aspects of DNA repair in the hyperthermophilic archaea (HA). Consistent with this assumption, proteins or enzymatic activities of baseexcision repair (BER), alkyl transfer, photo-reversal, and trans-lesion synthesis (TLS) pathways have been detected in HA which, aside from their temperature optima, seem to resemble their mesophilic counterparts. The BER enzymes found in HA include a variety of thermostable $\mathrm{N}$-glycosylases (Knaevelsrud et al. 2001; Yang et al. 2000; Sartori et al. 2001; Birkeland et al. 2002), whereas the TLS enzymes include several DNA polymerases of the $Y$ family (Boudsocq et al. 2001) It has also been reported that at least one of the uracil DNA glycosylases (Yang et al. 2002) and one of the Y-family polymerases (Grüz et al. 2001) associate with the PCNA-like sliding clamp in the corresponding HA. In addition, at least two studies have generated high-resolution structures of Yfamily polymerases of Sulfolobus (Ling et al. 2001; Zhou et al. 2002), providing valuable structural information for comparison to the functional properties of TLS polymerases in HA. These studies show, for example, that the low geometric selectivity of the catalytic site encourages the generation of frameshift mutations even at non-repetitive DNA sequences (Kokoska et al. 2002).

Unusual biochemical properties also appear among DNA enzymes of HA, however. A type 1B DNA topoisomerase exhibits AP lyase activity, for example, which represents a novel combination of enzyme activities (Belova et al. 2001). More recently, a single-subunit DNA polymerase encoded by a Sulfolobus plasmid has been found to have ATPase and DNA primase activities, representing a new class of DNA polymerases (Lipps et al. 2003). Of particularly broad significance for $H A$ is the fact that their B-family polymerases, which appear to include the replicative enzymes, stall when they encounter uracil residues in the template strand. This property, first reported by Lasken et al. (1996), has recently been shown to result from a uracil-specific binding pocket in the polymerase that scans the template strand $4-6$ nt ahead of the catalytic site (Fogg et al. 2002).
The biological function attributed to this feature is prevention of replication past deaminated cytosine residues, thereby avoiding $\mathrm{C}$-to- $\mathrm{T}$ transition mutations. What has received less attention, however, is how the cell is supposed to rescue the stalled complex, repair the template strand, and resume DNA synthesis, and why polymerases with this feature should be widespread among thermophilic archaea but not among thermophilic bacteria, which nevertheless tend to have DNAs of higher $\mathrm{G}+\mathrm{C}$ content. In particular, the fact that the complex stalls with the uracil residue in SSDNA protected by the enzyme (Fogg et al. 2002) would seem to preclude conventional BER. In principle, dissociation of the polymerase and regression of the replication fork could allow the uracil-containing strand to reanneal to its original partner so that BER could repair the lesion. Alternatively, displacement of the replicative polymerase by a specialized TLS polymerase could, in principle, allow for accurate replication past the uracil, in a manner analogous to replication of certain TLS polymerases past UV photoproducts (Boudsocq et al. 2001; Goodman 2002). In any event, without some form of rescue, the stalled complex would eventually insert an A opposite the $U$ and continue, as judged by assays in vitro (Fogg et al. 2002). It will be important to resolve these mechanistic questions in the future, and to resolve the phylogenetic distribution of this polymerase feature. Sequence alignments suggest it may not occur in the Bfamily DNA polymerases of psychrophilic or mesophilic archaea (Fogg et al. 2002), raising a question as to whether this feature is required for successful DNA replication in archaea that grow optimally at low temperatures.

\section{Important proteins missing}

Given the plausible arguments that hyperthermophiles should experience higher rates of spontaneous DNA damage than other organisms, the absence of certain highly conserved DNA repair proteins in HA attracts special attention. Table 1 summarizes the distribution of homologues of NER and MMR proteins in species of archaea and bacteria whose genomes have been sequenced. The pattern among archaea could be called "The Great Irony"; only those archaea that grow optimally at high temperatures lack critical components of the versatile and otherwise highly conserved NER and MMR pathways. Specifically, NER damage-recognition proteins are missing, whether of the XPA/Rad4 and XPC/Rad1 types found in eukaryotes, or of the UvrA and UvrB types found in bacteria. In contrast, structure-specific nucleases of eukaryotic NER are well-represented. Similarly, although some HA encode MutS-like proteins, these belong to a family of proteins with no demonstrated role in MMR (Rossolillo and Albertini 2001), whereas orthologues of MMR-specific proteins (MutS and MutL) do not occur in HA. This absence of genes encoding identifiable damage-recognition proteins is so far without exception in all of the completely sequenced genomes of $\mathrm{HA}$ (which numbered 11 at the time of writing) and appears unique to the HA, based on the available genomic sequences of thermophilic archaea, mesophilic archaea, and hyperthermophilic bacteria. 


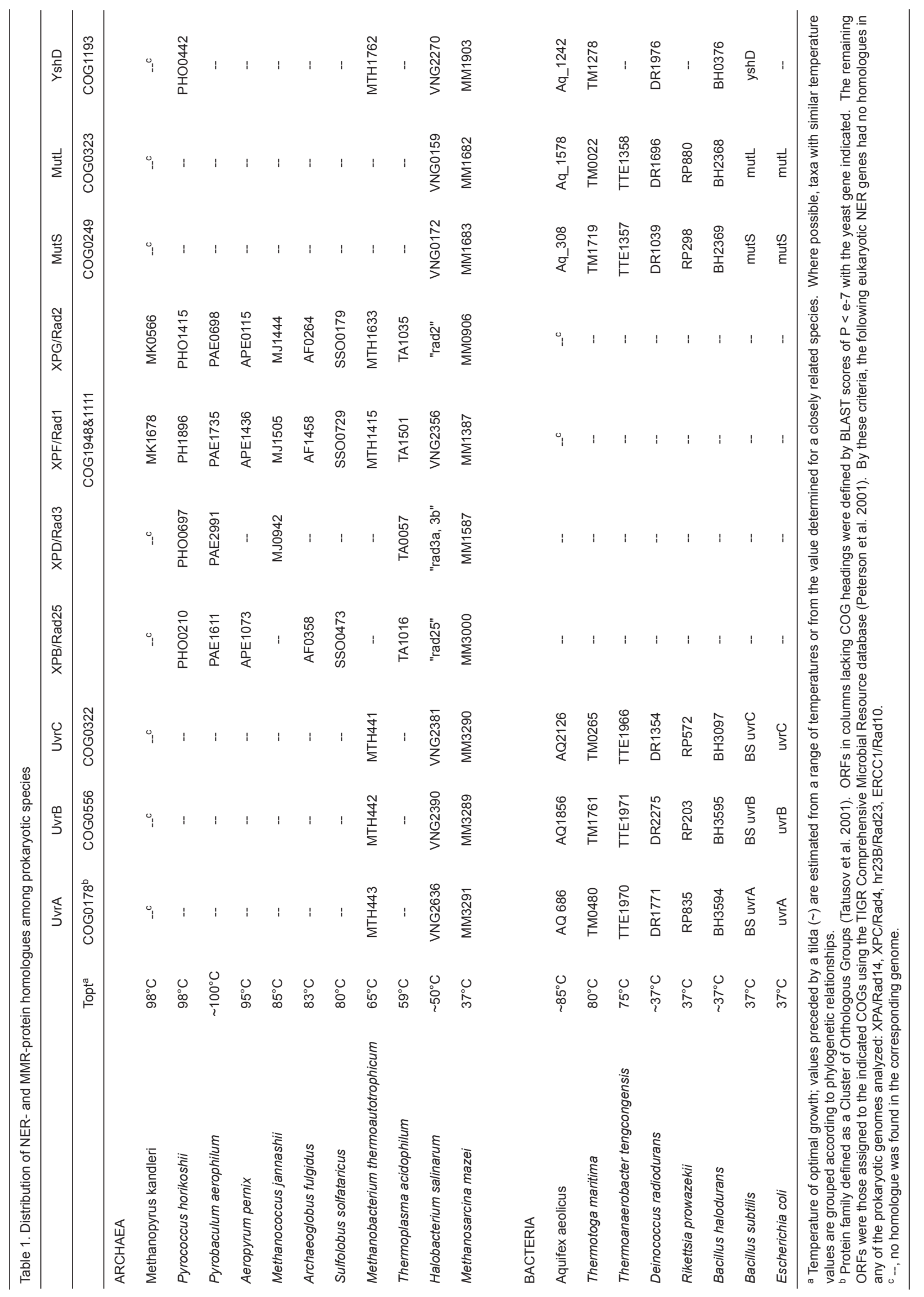




\section{Do hyperthermophilic archaea have an alternative form of NER?}

All bacterial genomes that have been sequenced, including the highly reduced genomes of intracellular parasites, encode UvrABC homologues, whereas sequenced eukaryotic genomes, with one exception (Gardner et al. 2002), encode complete sets of XP homologues. This strong conservation of functional pathways outside the hyperthermophilic archaea argues that NER is important for the evolutionary success of free-living organisms and many parasites. All HA genomes sequenced to date indeed encode some homologues of eukaryotic NER nucleases (Table 1), and one of these was recently reported to associate with the PCNA-like sliding clamp (Roberts et al. 2003). In addition, properties of certain HA suggest the operation of a DNA repair system with functions similar to those of NER. UV survival curves, for example, indicate that Sulfolobus acidocaldarius has at least half the darkrepair capacity of NER-proficient E. coli (Wood et al. 1997). Also, UV-C radiation stimulates conjugational DNA exchange and recombination in this species (Wood et al. 1997), and the kinetics of this stimulation are consistent with the enzymatic conversion of UV photoproducts into recombinogenic lesions and subsequent repair of those lesions (Schmidt et al. 1999). Taken together, therefore, the data suggest that HA have some functional equivalent of NER which uses yet-unknown proteins to recognize UV photoproducts, but may use homologues of eukaryotic NER proteins to complete the repair process.

\section{Do hyperthermophilic archaea have an alternative form of MMR?}

Unlike NER proteins, the proteins required for classical MMR define only two families, MutS and MutL, which span the bacterial and eukaryotic domains. In E. coli, MutS and MutL interact with each other to identify DNA mismatches and target them for repair. Accordingly, all organisms known to carry out post-replicational MMR encode at least one homologue of each family; eukaryotes differ from bacteria primarily in having multiple homologues exhibiting greater specialization of function (Nakagawa et al. 1999). The biological consequence of MMR is suppression of spontaneous mutation and homologous recombination between similar but non-identical sequences (Modrich and Lahue 1996). In yeast, the anti-recombination function can be resolved genetically from the mutation-avoidance function by certain alleles of the mutL homologue PMS1 (Welz-Vogele et al. 2002).

MMR-proficient bacteria generally exhibit rates of spontaneous mutation around $10^{-7}$ events per gene per cell division, whereas mutS or mutL mutants exhibit about 100 fold higher rates, making them relatively easy to recognize on this basis (Matic et al. 1997). Accurate measurement of loss-of-function mutation in the pyrE and pyrF genes have shown that the rate of spontaneous mutation in $S$. acidocaldarius is at or below the level of MMR-proficient E. coli (Jacobs and Grogan 1997; Grogan et al. 2001). Frequencies of spontaneous mutations appear to be comparable in other HA assayed by similar selections, with the exception of Sulfolobus solfataricus. [In this species, the mutational spectrum is overwhelmed by the frequent transposition of insertion sequences (Martusewitsch et al. 2000), which are extremely abundant in its genome (She et al. 2001).] Several mutator strains of S. acidocaldarius have been isolated which do not exhibit any obvious growth defects or sensitivity to DNA-damaging agents (Bell and Grogan 2001). This indicates that the mutationavoidance systems can be inactivated or saturated without compromising viability.

Taken together, the data suggest that Sulfolobus spp., and perhaps other $\mathrm{HA}$, have effective mechanisms of mutation-avoidance which do not involve homologues of the E. coli MutS and MutL proteins. On the other hand, Pyrobaculum aerophilum has been claimed to be a natural mutator, based on the frequency of recovering sequence variants from its genomic DNA (Fitz-Gibbon et al. 2001), and this possibility warrants experimental confirmation. The picture is further complicated by the prominence of slipped-strand events in the spontaneous mutational spectrum of S. acidocaldarius (Grogan et al. 2001). This is a characteristic of MMR-deficient systems (Tran et al. 1997), which raises questions regarding the extent to which post-replicational MMR contributes to the genetic fidelity observed in S. acidocaldarius.

\section{Hyperthermophilic bacteria}

Genomes of several bacteria which grow optimally at temperatures near or above $80^{\circ} \mathrm{C}$ have also been sequenced (Table 1). These hyperthermophilic bacteria encode full sets of NER and MMR genes, but few published studies have assessed the corresponding enzyme activities, DNA repair capacity, or genetic fidelity of these bacteria, most of which are strict anaerobes. Aerobic bacteria of the genus Thermus, which can grow at temperatures above $70^{\circ}$ $C$ have been studied more systematically in genetic terms, however. Results of one recent study (Castan et al. 2003) indicate a high spontaneous mutation rate in Thermus thermophilus, which is further elevated by inactivating this bacterium's recA gene. This observation raises the possibility that conventional MMR may not suppress spontaneous mutation as effectively in Thermus spp. or hyperthermophilic bacteria as in mesophilic bacteria. It should also be noted that a number of thermostable DNA repair proteins have been isolated from Thermus spp. and characterized. These include DNAN-glycosylases (Mikawa et al. 1998; Starkuviene and Fritz 2002), DNA photolyase (Kato et al. 1997), and MutS homologues (Takamatsu et al. 1996).

\section{Challenges for the near future}

As interest in DNA repair mechanisms intensifies and biochemical data regarding individual proteins accumulate, it becomes critical to appreciate the tremendous molecular diversity of prokaryotes and our extremely limited knowledge of the cellular and molecular biology of HA. Many DNA-repair proteins studied in model systems have broadly conserved paralogues with no obvious role in DNA stabilization or repair. These are exemplified by the YshD protein of Bacillus subtilis (Rossolillo and Albertini 2001), relatives of which represent the only MutS 
homologues in many archaea (Table 1). Also, some DNA repair mechanisms of HA resemble those of well-studied organisms, whereas others clearly deviate from them at fundamental levels. In this context, simplistic claims for the biological significance of an archaeal gene based upon its most famous $E$. coli or yeast homologue lose their validity and deserve appropriate skepticism. At the same time, opportunities to confirm DNA repair functions in vivo remain scarce and difficult, reflecting the technical limitations of manipulating HA. As a result, we have no firm measure of the complexity and functional overlap of DNA stabilization and repair systems in HA, nor the extent to which they participate in "normal" or essential DNA transactions. These cautions must be borne in mind as individual components of DNA stabilization and repair become identified. What we do know nevertheless suggests at least three efforts as being especially significant and timely.

\section{Identify protein-protein and protein-DNA interactions relevant to an alternative NER-like system}

At least three lines of evidence suggest a functional equivalent of NER in HA: i) UV-C survival curves and kinetics of UV-induced recombinogenesis in $S$. acidocaldarius (Wood et al. 1997; Schmidt et al. 1999), ii) conservation of XPF/Rad1 and XPG/Rad2 homologues in Sulfolobus and other HA (Table 1), and iii) biochemical properties of the XPF/Rad1 homologue of $S$. solfataricus (Roberts et al. 2003). Finding proteins that interact with the archaeal XPF and XPG homologues provides one promising route to revealing additional components of the NER equivalent pathway in HA, which are not evident from gene sequences. In addition, two of the three PCNA homologues of $S$. solfataricus have been found to interact with the XPF/Rad1 homologue of this species, and to stimulate its activity in vitro (Roberts et al. 2003). Given the fact that interaction of DNA-repair enzymes with PCNA is a prominent theme in eukaryotes (Maga and Hubscher 2003), identification of PCNA-associated proteins may uncover other DNA repair proteins in HA. Alternatively, the use of damaged DNA to bind proteins specifically may enable the elusive damage-recognition proteins of NER to be recovered and identified in a more direct manner.

\section{Determine whether a form of post-replicational MMR} operates in hyperthermophilic archaea

As described above, the available genetic data demonstrate effective mutation suppression in one Sulfolobus species, but leave unresolved its conservation among other HA and the nature of its molecular mechanism. The lack of MutS and MutL homologues in all HA and many other archaea analysed to date (Table 1) increases the significance of this question, and highlights the challenge of characterizing an MMR mechanism that may use novel proteins. The problem calls for experiments testing a range of hypotheses (including unconventional ones) that accommodate the various phylogenetic and biochemical data available.

In particular, if Sulfolobus spp. and other HA indeed use one or more unusual proteins to remove mismatches following replication, it is important to re-evaluate the essential requirements of MMR with respect to how archaeal proteins might recognize DNA mismatches and how repair could be confined to the newer (i.e. daughter) strand. For example, one possible explanation for the simultaneous lack of identifiable damage-recognition proteins for both MMR and NER is that HA have a common damage-recognition system that serves both MMR- and NER-like pathways. Such a protein (or set of proteins) could deviate with respect to sequence from the known NER and MMR proteins but remain functionally analogous to them by employing a lesion-binding mechanism based on induced DNA bending. This idea reflects the recent structural data which show that MutS, (UvrA $)_{2}$ UvrB, and XPA proteins all induce a sharp bend or curve in dsDNA when they bind to their corresponding lesions (Hsieh 2001; Schofield et al. 2001; Batty and Wood 2001; Missura et al. 2001). This shared feature of these diverse proteins suggests that localized weakening of the DNA duplex by a variety of lesions can "trap" proteins having an inducedfit mode of binding of the proper affinity. Small dsDNAbinding proteins of Sulfolobus such as Sac7d have several properties predicted for such damage-sensors. Although these small, rigid proteins have been portrayed primarily as chromatin-structuring proteins, their ability to induce sharp bends in normal duplex DNA and at a mismatch (Robinson et al. 1998; Su et al. 2000) mimics that of known damagerecognition proteins. Alternatively, a protein similar to DNA methyl transferases or other enzymes that abstract ("flip out") bases from the duplex as part of their catalysis could, in principle, probe duplex DNA for lesions. In this mode, the hypothesized protein may scan the intact helix but remove and bind with high affinity only bases whose normal stacking and hydrogen-bonding are perturbed by mismatch or covalent damage on an adjacent or opposing nucleotide. This interaction would be analogous to what has been observed for other DNA repair enzymes, such as DNA photolyase and uracil DNA N-glycosylases (Christine et al. 2002; Parihk et al. 2000).

The question of how an archaeal MMR system could discriminate daughter strand from template at a mismatch has special interest because the molecular basis of strand discrimination remains obscure in most organisms. This reflects the fact that Dam/MutH-directed MMR, analyzed so elegantly in $E$. coli, does not occur in eukaryotes or most bacteria. However, nicks in the daughter strand near the mismatch, which is the immediate result of the Dam/MutH system, seems to represent a more-general strand discriminator, as proposed by Lacks and others based on MMR in Gram-positive bacteria (Claverys and Lacks 1986). In Lacks' model, the discontinuity needed to mark the lagging daughter strand is provided most simply by Okazaki fragments. The leading strand could be made discontinuous as well, however, by re-initiation of synthesis, or low-level incorporation of dUMP and subsequent processing by BER enzymes (Claverys and Lacks 1986).

The known properties of HA seem broadly consistent with these proposed mechanisms. Like eukaryotes, HA synthesize short Okazaki fragments (Matsunaga et al. 2003), and the family B DNA polymerases of HA do not discriminate effectively against dUTP (Lasken et al. 1996). Indeed, this latter property, in combination with their unique sensitivity to $U$ residues in the template strand, can 
limit the effectiveness of the native polymerases in PCR (Hogrefe et al. 2002). It is therefore interesting to note that a hypothetical marking of the daughter strand for MMR by periodic incorporation of $U$ residues suggests a biological rationale for the peculiar stalling of HA DNA polymerases. If incorporation of $U$ residues into the nascent strand were relatively frequent, DNA synthesis past a $U$ residue in the template strand would create a significant risk that, after replication, BER would convert closely apposed $U$ residues into double-strand breaks. Thus, whereas avoidance of Cto-T transitions remains a plausible, long-term benefit of the "read-ahead proofreading" function of these polymerases (Fogg et al. 2002), avoidance of double-strand break formation would be acutely important for DNA replication and survival. It should also be noted that the eventual insertion of $A$ opposite $U$ by the polymerase would not be mutagenic in cases where the template $U$ residue were an unrepaired nascent-strand marker from the prior round of replication.

Finally, it is interesting to note that Lacks' model of daughter-strand marking by discontinuity provides a simple way for an hypothetical MMR system to remove the newly synthesized strand specifically. If two helicases of opposite polarity were recruited to the mismatch in a manner analogous to eukaryotic NER, their uncontrolled translation along the DNA in both directions would ultimately displace the discontinuous (daughter) strand from the continuous (template) strand. Destruction of the displaced strand by single-strand-specific exonucleases or other means would thereby remove the incorrect base of the mismatch and prepare the template for re-synthesis of a correct daughter strand.

3. Confirm the relevance of specific proteins to DNA stability and repair in vivo

Research on HA must rely currently on similarities among primary structures and biochemical properties to infer which proteins are relevant for DNA stabilization and repair. As these criteria can be confounded by paralogues and functional divergence between $\mathrm{HA}$ and model systems, they do not conclusively establish biological function in vivo, which represents a major goal of this area of research. Thus, experimental methods are needed which can be applied to living archaeal cells. Foremost among these are methods to inactivate putative DNA-repair genes and document the phenotypes of the resulting mutants. Some encouraging progress in cloning and targeted gene disruption has been reported recently for certain Pyrococcus, Thermococcus and Sulfolobus species (Lucas et al. 2002; Sato et al. 2003; Worthington et al. 2003). ORFs which have been annotated as non-essential DNA-repair genes would seem to provide ideal test-cases for the utility of these published methods. In most cases, the corresponding species should also support some basic biological assays of DNA stability and repair, such as radiation survival, homologous recombination, induced mutation, or spontaneous mutation.

\section{Acknowledgements}

Work in the author's laboratory was supported by a grant from the National Science Foundation (MCB9733303).

\section{References}

Battista J.R. (1997) Against all odds: the survival strategies of Deinococcus radiodurans. Ann. Rev. Microbiol. 51, 203-24.

Battista, J.R. (2000) Radiation resistance: the fragments that remain. Current Biology 10, R204-205.

Batty, D.P. and Wood, R.D. (2000) Damage recognition in nucleotide excision repair of DNA. Gene 241, 193-204.

Bell, G.D. and Grogan, D.W. (2002) Loss of genetic accuracy in mutants of the thermoacidophile Sulfolobus acidocaldarius. Archaea 1, 45-52.

Belova, G.I., Prasad, R., Kozyavkin, S.A., Lake, J.A., Wilson, S.H. and Slesarev, A.I. (2001) A type IB topoisomerase with DNA repair activities. Proc. Nat. Acad. Sci. USA 98, 6015-6020.

Birkeland, N.-K., Anensen, H., Knaevelsrud, I., Kristoffersen, W., Bjoras, M., Robb, F.T., Klungland, A., and Bjelland, S. (2002) Methylpurine DNA glycosylase of the hyperthermophilic archaeon Archaeoglobus fulgidus. Biochem. 41, 12697-12705.

Boudsocq, F., Iwai, S., Hanaoka, F. and Woodgate, R. (2001) Sulfolobus solfataricus P2 DNA polymerase IV (Dpo4): an archaeal DinB-like DNA polymerase with lesion-bypass properties akin to eukaryotic pol(eta). Nucl. Acids Res. 29, 4607-4616.

Castan, P., Casares, L., Barbe, J. and Berenguer, J. (2003) Temperature-dependent hypermutational phenotype in recA mutants of Thermus thermophilus HB27. J. Bacteriol. 185, 4901-4907.

Christine, K.S., McFarlane, A.W. IV, Yang, K., and Stanley, R.J. (2002) Cyclobutane pyrimidine dimer base flipping by DNA photolyase. J. Biol. Chem. 277, 28339-38344.

Claverys, J.-P. and Lacks, S.A. (1986) Heteroduplex deoxyribonucleic acid base mismatch repair in bacteria. Microbiol. Rev. 50, 133-165.

Fitz-Gibbon, S.T., Ladner, H., Kim,U.J., Stetter, K.O., Simon, M.I., Miller, J.H. (2002) Genome sequence of the hyperthermophilic crenarchaeon Pyrobaculum aerophilum. Proc. Natl. Acad. Sci. USA 99, 984-989.

Fogg, M.J., Pearl L.H. and Connolly B.A. (2002) Structural basis for uracil recognition by archaeal family B DNA polymerases. Nat. Struct. Biol. 9, 922-927.

Gardner, M.J., Hall N., Fung E., White O., Berriman M., Hyman R.W., Carlton J.M., Pain A., Nelson K.E., Bowman S., Paulsen I.T., James K., Eisen J.A., Rutherford K., Salzberg S.L., Craig A., Kyes S., Chan M.S., Nene V., Shallom S.J., Suh B., Peterson J., Angiuoli S., Pertea M., Allen J., Selengut J., Haft D., Mather M.W., Vaidya A.B., Martin D.M., Fairlamb A.H., Fraunholz M.J., Roos D.S., Ralph S.A., McFadden G.I., Cummings L.M., Subramanian G.M., Mungall C., Venter J.C., Carucci D.J., Hoffman S.L., Newbold C., Davis R.W., Fraser C.M., Barrell B. (2002) Genome sequence of the human malaria parasite Plasmodium falciparum. Nature 419, 498-511.

Goodman, M.F. (2002) Error-prone DNA polymerases in prokaryotes and eukaryotes. Ann. Rev. Biochem. 71, 17-50.

Grogan, D.W. (1998) Hyperthermophiles and the problem of DNA instability. Mol. Microbiol. 28, 1043-1050. 
Grogan, D.W. (2000) The question of DNA repair in hyperthermophilic archaea. Trends Microbiol. 8, 180185.

Grogan, D.W., G.T. Carver, and J. W. Drake (2001) Genetic fidelity under harsh conditions: Analysis of spontaneous mutation in the thermoacidophilic archaeon. Sulfolobus acidocaldarius. Proc. Natl. Acad. Sci. USA 98, 79287933.

Grüz, P., Pisani, F.M., Shimizu, M., Yamada, M., Hayashi, I., Morikawa, K. and Nohmi, T. (2001) Synthetic activity of Sso DNA polymerase $\mathrm{Y} 1$, an archaeal DinB-like DNA polymerase, is stimulated by processivity factors Proliferating Nuclear Antigen and Replication Factor C. J. Biol. Chem. 276, 47397-47401.

Hsieh, P. (2001) Molecular mechanisms of DNA mismatch repair. Mutat. Res. 486, 71-87.

Hogrefe, H.H., Hansen, C.J., Scott, B.R., Nielson, K.B. (2002) Archaeal dUTPase enhances PCR amplifications with archaeal polymerases by preventing dUTP incorporation. Proc. Nat. Acad. Sci. USA 99, 596-601.

Jacobs, K.L., and D.W. Grogan (1997) Rates of spontaneous mutation in an archaeon from geothermal environments. J. Bacteriol. 179, 3298-3303.

Karlin, S., Mrazek, J. (2001) Predicted highly expressed and putative alien genes of Deinococcus radiodurans and implications for resistance to ionizing radiation. Proc. Natl. Acad. Sci. U.S.A. 98, 5240-5245.

Kato, R. Hasegawa, K. Hidaka, Y., Kuramitsu, S., Hoshino, T. (1997) Characterization of a thermostable DNA photolyase from an extremely thermophilic bacterium, Thermus thermophilus HB27. J. Bacteriol. 179, 64996503.

Knaevelsrud, I., Ruoff, P., Anensen, H., Klungland, A., Bjelland, S. and Birkeland, N.-K. (2001) Excision of uracil from DNA by the hyperthermophilic Afung protein is dependent on the opposite base and stimulated by heat-induced transition to a more open structure. Mutat. Res. 487, 173-190.

Kokoska, R.J. K. Bebenek, F. Boudsocq, R. Woodgate, T.A. Kunkel. (2002) Low-fidelity DNA synthesis by a Y-family DNA polymerase due to misalignment in the active site. J. Biol. Chem. 277, 19633-19638.

Lasken, R.S., Schuster, D.M. and Rashtchian, A. (1996) Archaebacterial DNA polymerases tightly bind uracilcontaining DNA. J. Biol. Chem. 271, 17692-17696.

Lindahl, T. (1993) Instability and decay of the primary structure of DNA. Nature 362:709-715.

Lindahl T and Wood R.D. (1999) Quality control by DNA repair. Science 286, 1897-1905.

Lipps, G., Rother, S., Hart, C., and Strauss, G. (2003) A novel type of replicative enzyme harbouring ATPase, primase, and DNA polymerase activity. EMBO J. 22, 2516-2525.

Ling, H., Boudsocq, F., Woodgate, R. and Yang, W. (2001) Crystal Structure of a Y-Family DNA Polymerase in Action: A Mechanism for Error-Prone and Lesion-Bypass Replication. Cell 107, 91-102.

Lucas, S. Toffin, L., Zivanovic, Y., Charlier, D., Moussard, H., Forterre, P., Prieur, D. and Erauso, G. (2002) Construction of a shuttle vector for, and spheroplast transformation of the hyperthermophilic archaeon Pyrococcus abyssi. Appl. Environm. Microbiol. 68, 5528-5536.
Maga, G., Hubscher, U. (2003) Proliferating cell nuclear antigen (PCNA): a dancer with many partners. J. Cell Sci. 116, 3051-3060.

Martusewitsch, E., Sensen, C. and Schleper, C. (2000) High spontaneous mutation rate in the hyperthermophilic archaeon Sulfolobus solfataricus is mediated by transposable elements. J. Bacteriol. 182, 2574-2581.

Matic, I., Radman, M., Taddei, F., Picard, B., Doit, C., Bingen, E., Denamur E. and Elion, J. (1997) Highly variable mutation rates in commensal and pathogenic Escherichia coli. Science 277, 1833-1834.

Matsunaga F, Norais C, Forterre P, Myllykallio H. (2003) Identification of short 'eukaryotic' Okazaki fragments synthesized from a prokaryotic replication origin. EMBO Rep. 4, 154-158.

Mikawa, T., Kato, R., Sugahara, M., and Kuramitsu, S. (1998) Thermostable repair enzyme for oxidative DNA damage from the extremely thermophilic bacterium Thermus thermophilus HB8. Nucl. Acids Res. 26, 903910.

Missura, M., Buterin, T., Hindges, R., Hubscher, U., Kasparkova, J., Brabec, V. and Naegeli, H. (2001) Double-check probing of DNA bending and unwinding by XPA-RPA: an architectural function in DNA repair. EMBO J. 20, 3554-3564.

Modrich, P. and Lahue, R. (1996) Mismatch repair in replication fidelity, genetic recombination, and cancer biology. Ann. Rev. Biochem. 65, 101-133.

Nagawa, T., Datta, A. and Kolodner, R.D. (1999) Multiple functions of MutS- and MutL-related heterocomplexes. Proc. Nat. Acad. Sci. USA 96, 14186-14188.

Parikh, S.S., Putnam, C.D., Tainer, J.A. (2000) Lessons learned from structural results on uracil-DNA glycosylase. Mutation Res. 460, 183-199.

Peterson, J.D., Umayam, L.A., Dickinson, T.M., Hickey, E.K. and White, O. (2001) The Comprehensive Microbial Resource. Nucl. Acids Res. 29, 123-125.

Prakash, S. and Prakash, L. (2000) Nucleotide excision repair in yeast. Mutat. Res. 451, 13-24.

Roberts, J.A., Bell, S.D., and White, M.F. (2003) An archaeal XPF repair endonuclease dependent on a heterotrimeric PCNA. Mol. Microbiol. 48, 361-371.

Robinson, H., Gao, Y.-G., McCrary, B.S., Edmondson, S.P., Shriver, J.W., Wang, A. H.-J. (1998) The hyperthermophile chromosomal protein Sac7d sharply kinks DNA. Nature 392, 202-206.

Rossolillo, P. and Albertini, A.M. (2001) Functional analysis of the Bacillus subtilis $y s h D$ gene, a mutS paralogue. Molec. Gen. Genet. 264, 809-818.

Sartori, A.A., P. Schar, S. Fitz-Gibbon, J.H. Miller and J. Jiricny. (2001) Biochemical characterization of uracil processing activities in the hyperthermophilic archaeon Pyrobaculum aerophilum. J Biol. Chem. 276, 2997929986.

Sato, T., Fukui, T., Atomi, H. and Imanaka, T. (2003) Targeted gene disruption by homologous recombination in the hyperthermophilic archaeon Thermococcus kodakarensis KOD1. J. Bacteriol. 185, 210-220.

Schmidt, K. J., Beck, K., and Grogan, D.W. (1999) UV-stimulation of chromosomal marker exchange in Sulfolobus acidocaldarius: implications for DNA repair, conjugation, and homologous recombination at extremely 
high temperatures. Genetics 152, 1407-1415.

Schofield, M.J., Brownewell, F.E., Nayak, S., Du, C., Kool, E.T., and Hsieh, P. (2001) The Phe-X-Glu DNA binding motif of MutS. J. Biol. Chem. 276, 45505-45508.

She Q., Singh R.K., Confalonieri F., Zivanovic Y., Allard G., Awayez M.J., Chan-Weiher C.C., Clausen I.G., Curtis B.A., De Moors A., Erauso G., Fletcher C., Gordon P.M., Heikamp-de Jong I., Jeffries A.C., Kozera C.J., Medina N., Peng X., Thi-Ngoc H.P., Redder P., Schenk M.E., Theriault C., Tolstrup N., Charlebois R.L., Doolittle W.F., Duguet M., Gaasterland T., Garrett R.A., Ragan M.A., Sensen C.W., Van der Oost J. (2001) The complete genome of the crenarchaeon Sulfolobus solfataricus P2. Proc. Natl. Acad. Sci. USA 98, 7835-7840.

Stetter, K.O. (1996) Hyperthermophilic procaryotes. FEMS Microbiol. Rev. 18, 149-158.

Starkuviene, V., and Fritz, H.-J. (2002) A novel type of uracil-DNA glycosylase mediating repair of hydrolytic DNA damage in the extremely thermophilic eubacterium Thermus thermophilus. Nucl. Acids Res. 30, 20972102.

Su, S., Gao, Y.-G., Robinson, H., Liaw, Y.-C., Edmondson, S.P., Shriver, J.W., Wang, A. H.-J. (2000) Crystal structures of the chromosomal proteins Sso7d/Sac7d bound to DNA containing T-G base-pairs. J. Mol. Biol. 303, 395-403.

Takamatsu, S., Kato, R., and Kuramitsu, S. (1996) Mismatch DNA recognition protein from an extremely thermophilic bacterium, Thermus thermophilus HB8. Nucl. Acids Res. 24, 640-647.

Tatusov R.L., Natale D.A., Garkavtsev I.V., Tatusova T.A., Shankavaram U.T., Rao B.S., Kiryutin B., Galperin M.Y., Fedorova N.D., Koonin E.V. (2001) The COG database: new developments in phylogenetic classification of proteins from complete genomes. Nucl. Acids Res. 29,22-28.

Tran, H.T., J.D. Keen, M. Kricker, M.A. Resnick, D.A.
Gordenin. (1997) Hypermutability of homonucleotide runs in mismatch repair and DNA polymerase proofreading yeast mutants. Mol. Cell. Biol. 17, 2859-2865.

Welz-Voegele, C., Stone, J.E., Tran, P.T., Kearney, H.M., Liskay, R.M., Petes, T.D. and Jinks-Robertson, S. (2002) Alleles of the yeast PMS1 mismatch-repair gene that differentially affect recombination- and replication-related processes. Genetics 162, 1131-1145.

White, M. (2003) Archaeal DNA repair: paradigms and puzzles. Biochem. Soc. Trans. 31, 690-693.

Wood, E.R., Ghané, F., and Grogan, D.W. (1997) Genetic responses of the thermophilic archaeon Sulfolobus acidocaldarius to short-wavelength UV light. J. Bact. 179, 5693-5698.

Woese, C.R., Kandler, O. and Wheelis, M. (1990) Towards a natural system of organisms: Proposal for the domains Archaea, Bacteria, and Eucarya. Proc. Natl. Acad. Sci. USA 87, 4576-4579.

Worthington, P., Hoang, V. Perez-Pomares, F. and Blum, P. (2003) Targeted disruption of the alpha-amylase gene in the hyperthermophilic archaeon Sulfolobus solfataricus. J. Bacteriol. 185, 482-488.

Yang, H., Fitz-Gibbon, S, Marcotte, E.M., Tai, J.H., Hyman, E.C., and Miller, J.H. (2000) Characterization of a thermostable DNA glycosylase specific for $U / G$ and T/G mismatches from the hyperthermophilic archaeon Pyrobaculum aerophilum. J. Bacteriol. 182, 1272-1279.

Yang, H., Chiang, J.-H., Fitz-Gibbon, S., Lebel, M., Sartori, A., Jiricny, J., Slupska, M. and Miller, J.H. (2002) Direct interaction between uracil-DNA glycosylase and a Proliferating Cell Nuclear Antigen homolog in the Crenarchaeon Pyrobaculum aerophilum. J. Biol. Chem. 277, 22271-22278.

Zhou, B.L, Pata, J.D. and Steitz, T.A. (2001) Crystal structure of a DinB lesion bypass DNA polymerase catalytic fragment reveals a classic polymerase catalytic domain. Mol. Cell 8, 427-437. 


\section{Further Reading}

Caister Academic Press is a leading academic publisher of advanced texts in microbiology, molecular biology and medical research. Full details of all our publications at caister.com

- MALDI-TOF Mass Spectrometry in Microbiology Edited by: M Kostrzewa, S Schubert (2016) www.caister.com/malditof

- Aspergillus and Penicillium in the Post-genomic Era Edited by: RP Vries, IB Gelber, MR Andersen (2016) www.caister.com/aspergillus2

- The Bacteriocins: Current Knowledge and Future Prospects Edited by: RL Dorit, SM Roy, MA Riley (2016)

www.caister.com/bacteriocins

- Omics in Plant Disease Resistance Edited by: V Bhadauria (2016) www.caister.com/opd

- Acidophiles: Life in Extremely Acidic Environments Edited by: R Quatrini, DB Johnson (2016) www.caister.com/acidophiles

- Climate Change and Microbial Ecology: Current Research and Future Trend

Edited by: J Marxsen (2016)

www.caister.com/climate

- Biofilms in Bioremediation: Current Research and Emerging Technologies

Edited by: G Lear (2016)

www.caister.com/biorem

- Microalgae: Current Research and Applications Edited by: MN Tsaloglou (2016) www.caister.com/microalgae

- Gas Plasma Sterilization in Microbiology: Theory, Applications, Pitfalls and New Perspectives Edited by: H Shintani, A Sakudo (2016) www.caister.com/gasplasma

- Virus Evolution: Current Research and Future Directions Edited by: SC Weaver, M Denison, M Roossinck, et al. (2016) www.caister.com/virusevol

- Arboviruses: Molecular Biology, Evolution and Control Edited by: N Vasilakis, DJ Gubler (2016) www.caister.com/arbo

- Shigella: Molecular and Cellular Biology Edited by: WD Picking, WL Picking (2016) www.caister.com/shigella

-Aquatic Biofilms: Ecology, Water Quality and Wastewater Treatment

Edited by: AM Romaní, H Guasch, MD Balaguer (2016)

www.caister.com/aquaticbiofilms

- Alphaviruses: Current Biology

Edited by: S Mahalingam, L Herrero, B Herring (2016)

www.caister.com/alpha

- Thermophilic Microorganisms

Edited by: F Li (2015)

www.caister.com/thermophile
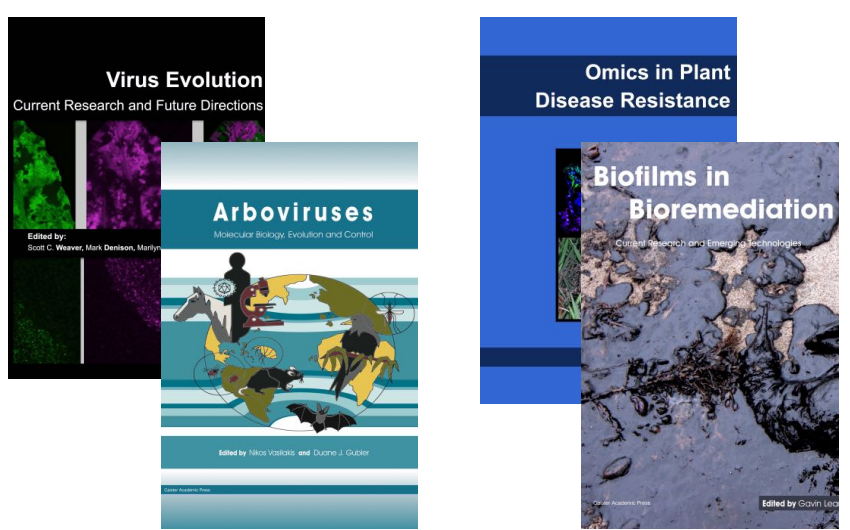
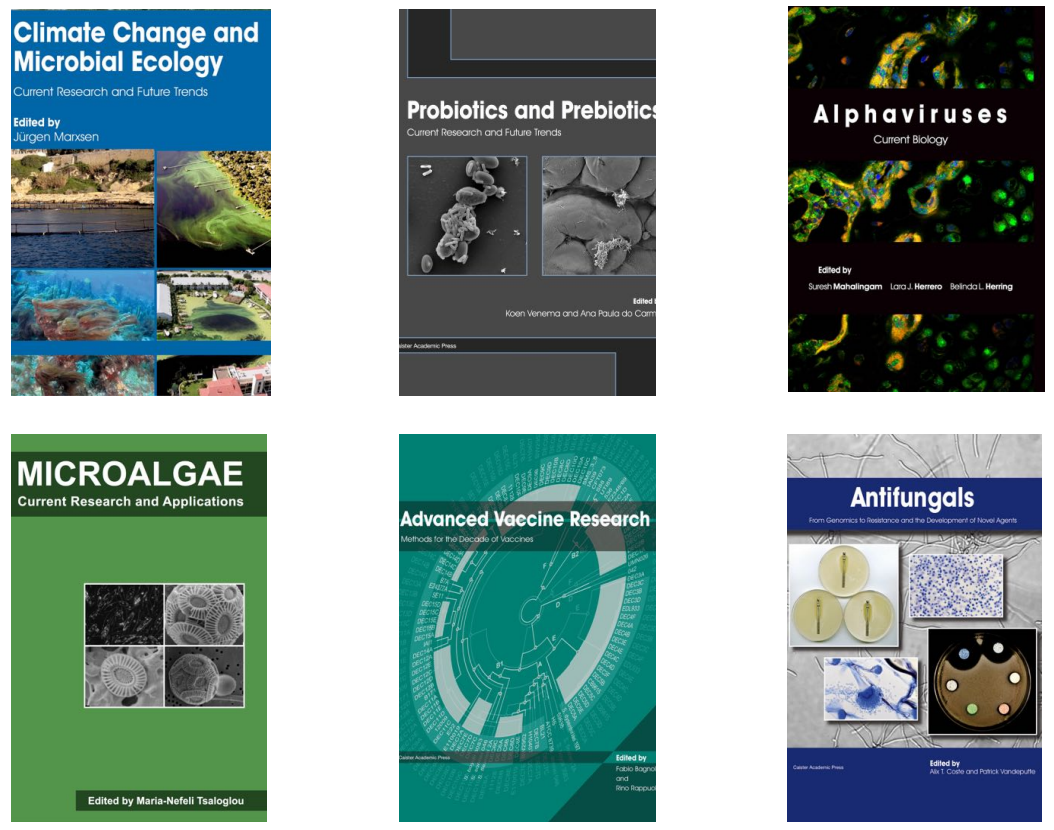

- Flow Cytometry in Microbiology: Technology and Applications Edited by: MG Wilkinson (2015) www.caister.com/flow

- Probiotics and Prebiotics: Current Research and Future Trends Edited by: K Venema, AP Carmo (2015) www.caister.com/probiotics

- Epigenetics: Current Research and Emerging Trends Edited by: BP Chadwick (2015) www.caister.com/epigenetics2015

- Corynebacterium glutamicum: From Systems Biology to Biotechnological Applications

Edited by: A Burkovski (2015)

www.caister.com/cory2

- Advanced Vaccine Research Methods for the Decade of Vaccines

Edited by: F Bagnoli, R Rappuoli (2015)

www.caister.com/vaccines

- Antifungals: From Genomics to Resistance and the Development of Novel Agents

Edited by: AT Coste, P Vandeputte (2015)

www.caister.com/antifungals

- Bacteria-Plant Interactions: Advanced Research and Future Trends Edited by: J Murillo, BA Vinatzer, RW Jackson, et al. (2015) www.caister.com/bacteria-plant

\section{- Aeromonas}

Edited by: J Graf (2015)

www.caister.com/aeromonas

- Antibiotics: Current Innovations and Future Trends

Edited by: S Sánchez, AL Demain (2015)

www.caister.com/antibiotics

- Leishmania: Current Biology and Contro Edited by: S Adak, R Datta (2015) www.caister.com/leish2

- Acanthamoeba: Biology and Pathogenesis (2nd edition) Author: NA Khan (2015)

www.caister.com/acanthamoeba2

- Microarrays: Current Technology, Innovations and Applications Edited by: Z He (2014)

www.caister.com/microarrays2

- Metagenomics of the Microbial Nitrogen Cycle: Theory, Methods and Applications

Edited by: D Marco (2014)

www.caister.com/n2 